\title{
From Tapestry to Loom: Broadening the Perspective on Values in Science
}

\author{
Heather Douglas*
}

\begin{abstract}
After raising some minor philosophical points about Kevin Elliott's $A$ Tapestry of Values (2017), I argue that we should expand on the themes raised in the book and that philosophers of science need to pay as much attention to the loom of science (i.e., the institutional structures which guide the pursuit of science) as the tapestry of science. The loom of science includes such institutional aspects as patents, funding sources, and evaluation regimes that shape how science gets pursued, and that attending to these aspects will enable us to provide more robust guidance on the values that infuse the tapestry of science.
\end{abstract}

\section{Keywords \\ values in science $\cdot$ patents in science $\cdot$ dangerous research}

Part of an author-meets-critics book symposium on A Tapestry of Values: An Introduction to Values in Science by Kevin C. Elliott (Oxford University Press, 2017), with Elliott 2018a and 2018b, Kourany 2018, and Brown 2018

Kevin Elliott's recent book, A Tapestry of Values: An Introduction to Values in Science, is an admirably clear book, written in deft prose, and crammed full of examples to think about the relationship between values and science. The examples make the book particularly rich for teaching-one can track down further details from the examples given using the suggested readings at the end of each chapter and flesh out further the accounts for one's students. For those struggling to let go of the value-free ideal for science, Kevin's book provides an accessible and friendly entrée into the many ways social and ethical values are important for science.

The central metaphor of the book, that values weave themselves into scientific practice like the weaving of a tapestry, is a helpful one. The examples Kevin discusses show how value judgments are an important part of scientific work across a range of decision points scientists face. Further, once the values are woven into the fabric of science, they cannot be squeezed out. Instead, the examples show how the values shape the direction and texture of science, and, unlike a dye that could be evaporated off or bleached out, the values are threads that make up the structure and strength of the science. One can untangle the threads, to sort out the precise

*Department of Philosophy, Michigan State University, 503 South Kedzie Hall, East Lansing, MI 48824 USA, doug1239@msu.edu

Received 17 July 2018; Accepted 29 July 2018 doi:10.3998/ptpbio.16039257.0010.008

○ OPEN ACCESS - PTPBIO.ORG 
value influences, but doing so unweaves the science, and one is left with no fabric at all, no scientific knowledge at all, after such an untangling. In addition, we cannot see easily how the science would have gone with different value judgments. We do not know, for example, how research for depression treatments would have gone in an alternative world where there were no drug patents, and thus no incentive to research primarily patentable treatments. We don't live in that world, and we would need to redirect medical research efforts to find out. Thus, we can change the fabric of science by making different value judgments, but we cannot readily tell what the fabric would look like if we had made different judgments and choices in the past. Counterfactual weaving of science is beyond us; we have to actually do different science to see how it would (or would not) change. Further, as we continue to pursue science, there is no way to make the fabric without such value threads. As Kevin shows in example after example, the choices scientists make, either wittingly or not, bring values into science. It would be better, Kevin argues, to be aware of this and to make such threads explicit where we can.

The metaphor of the tapestry is thus an apt one for science, moving us past (finally!) the foundationalist metaphors of facts as bricks that have had the values baked out of them (as if the values were like water, essential for making the brick but eliminable). But I want to suggest in this commentary that the tapestry metaphor is even more helpful, because every tapestry we weave requires a loom. And it is the loom of science, the institutional and cultural frameworks that structure science, that requires as much attention as the tapestry.

I do have some philosophical quibbles with Kevin's book. Let me get those out of the way.

The first is that the book carves up the ways in which values influence science with lots of fuzzy boundaries. Chapters 2-4, for example, address the influence of values on what we choose to study (chapter 2), how we choose to study it (chapter 3), and what the aim of research is (chapter 4). But in the examples used to illustrate these choices (and the values that influence them), I found it hard to tell why an example was used in one chapter rather than another. For example, Kevin examines controversies over agricultural research in chapter 3 (how we choose what to study), comparing the focus on genetic modification combined with chemical inputs on the one hand, with agroecological approaches that produce more locally relevant possibilities on the other (Elliott 2017, 43-48). But this could be just as readily analyzed in terms of what we choose to study (which kinds of inputs into agricultural practices are of interest to scientists) or what the aims of research should be (do we want globally plausible interventions that might work unevenly or locally optimal interventions). Another example: A section in chapter 4 entitled "Choosing theories to pursue" (68-71) (which discusses gendered theories of human development in anthropology) seems like it could just as well have been in chapter 2 , as it is about how aims influence the choice of theory to pursue, which is also about what we choose to study.

Or consider the issue of science communication (as opposed to discourse internal to science). The issue of how scientists discuss their work with those outside the scientific community comes up first in chapter 5 ("What if we are uncertain?") and then is tackled again in chapter 6 ("How should we talk about it?"). For philosophers, the kinds of overlap in organizational strategies deployed in the book can be frustrating.

This frustration is ameliorated, however, if one considers that the book is not meant (just) for philosophers, but rather non-philosophers, and it might be particularly helpful to have such a blurry category approach for one target audience-budding scientists. By having overlapping and entangled categories structuring the book, Kevin is showing how rich the tapestry of values in science actually is, and how thoroughly saturated scientific practice can be with important value judgments, usually without threatening the reliability of scientific endeavors (although Kevin does address cases like Lysenko where the reliability of science was severely damaged 
with disastrous results). The book displays repeatedly how there is no way forward in doing science without making some kind of value judgment, whether that judgment is implicit or explicit. To do science is to make choices about what should be done (and also what should not be done) throughout the research process, and those choices shape (but do not determine) the science that results.

Another quibble I have is over the characterization of direct and indirect role for values in science. In his discussion of these roles, Kevin writes that: "Values influence scientists directly when values are treated as if they are a form of evidence" (93). This is not an accurate characterization of the direct (vs. indirect) role, however. I have talked about values in the direct role being a reason in themselves for some choice (which can be a normative reason, not just evidence) and values in the indirect role being a reason for accepting the sufficiency of support (reasons and/or evidence) for a choice (Douglas 2016). Translating this distinction so that it is in line with the aims-oriented approach to values in science championed elsewhere by Kevin (e.g., Elliott and McKaughan 2014), we could describe values in the direct role as determining what makes a choice good (what is the scientist aiming to do, e.g., improve public health, make a profit for their company, etc.), whereas values in the indirect role tell us what makes a choice good enough. In neither case are values treated as a form of evidence.

But these are just quibbles. What is more interesting to me is shifting from the individual scientist's value-based choices (the focus of most of the book) to the institutional level analysis of the impact of values on science (which comes up in the beginning and end of the book, but is not the main focus). It is the shift from the weaving of the tapestry to the shape of the loom.

That we need to look at both the tapestry and the loom can be seen in the norms Kevin advocates for dealing with values in science. He proposes a three-pronged approach for dealing with social and ethical values in science: the values should be transparent, the values should be "representative of our major social and ethical priorities," and "they should be scrutinized through appropriate processes of engagement between different scholars and other stakeholders" (Elliott 2017, 10). I have two minor points about these norms: (1) Transparency is a problematic ideal from the perspective of both scientists' self-knowledge (Are scientists aware enough to make all their judgments transparent?) and science communication (Wouldn't the audience be overwhelmed by too many details if all judgments were made transparent?). I would recommend that this ideal be articulated instead either in terms of openness (about the important choices one makes and the reasons for those choices) or in terms of explicitness (where crucial judgments and the values involved are made clear, but not all judgments). It is key that scientists get past the normative hang-up of the value-free ideal so that they are more comfortable discussing the values that are part of their practice. But transparency might be too crystalline an aim, and thus hamper that effort. (2) Kevin notes that these aims "tend to coincide," but I think one can say something stronger (172). They not only tend to coincide; they pull together. Engagement (in the way described in the book, particularly with various publics) makes both the values used more explicit and more representative of the public's interest (Douglas 2005; Cavalier and Kennedy 2016). It is difficult to see how promoting one of these goals does not promote the others as well.

Throughout the book, these norms for values in science are usually discussed in terms of individual scientists' choices-what scientists as individuals need to be clear about, how they should assess the values in their own work, and how they should pursue different kinds of engagement. Yet in discussions of the social and institutional structures around science (like his discussion of funding for science in chapter 2 or his discussion of patents in science in chapter 7 ), we can see that scientists' choices can be quite limited by institutional structures. Consider patents as part of the intellectual property regime within which science operates. Patents can 
be used to limit access to certain lines of investigation (Biddle 2014; Brown 2008). Patents can also create strong, nearly irresistible incentives to work on some lines of research and not others, particularly when funding sources line up with the push to create patentable results. This is well documented in medical and agricultural research (ibid.). Patents thus shape research agendas, and this is within a system of science funding which is increasingly relying on private rather than public sources. In Canada under the Harper administration (2006-2015), federal funding for researchers at universities began to require matching funds from another source, which created a strong incentive to do research that one can find a private business willing to help fund (Douglas 2015). Under the current Trudeau administration, concerns have been expressed about the influence of the demand for matching funds on distorting discovery grants (the basic science funding grant in Canada), but it is not clear that policies have changed (Naylor et al 2017). The desire to direct science towards economic and business-oriented ends remains strong, across countries.

If scientists must work within existing institutional structures, and such structures deeply influence the values that shape the fabric of research, both scientists and philosophers of science need to get better at examining the institutional structures and cultures of science. Further, we need to do more than just noting the importance of these structures and cultures; we need to normatively evaluate them and make recommendations for how things might be done differently. Comparative work across different science policy jurisdictions can help here. In his book, for example, Kevin discusses the insightful work of Shobita Parthasarathy comparing patent policy in the US and the EU (Parthasarathy 2017). In the EU, patents can be challenged on social and ethical value grounds. Such an opportunity does not necessarily change whether a patent is granted, but it changes the public justification for a patent and the grounds for public debate about a patent. As we move into more and more contested ground for biotechnology, we may see this divergence in patent law take on increased importance. In Canada, it is illegal to patent whole complex organisms (although not their genes), whereas in the US it is legal to patent whole organisms (Kondro 2002; Kevles 2002). We could use these subtle jurisdictional differences to see whether small changes in patent law would positively or negatively influence the course of science.

However, it might be that we need to think bigger. The existence of patents in biomedical research has come under searing criticism (Brown 2009; Reiss 2010). We might well wonder whether patents are defensible entities at all in today's corporate landscape. Patents were originally intended to provide a temporary monopoly to an inventor in exchange for making their knowledge publicly available, short term protection in order to incentivize innovation and support the individual inventor. (See Belt 2010, 195-202, for a brief history.) This might have made sense in the eighteenth and nineteenth centuries, but by the twenty-first century, the incentives and social locations for innovation have changed. Wealthy corporate actors dominate the patent landscape. It costs about $\$ 20,000$ (to $\$ 30,000$ in Canada) to file for a patent, and that is not because of the fee from the patent office but because of the fees charged by a patent lawyer, which you generally need in order to be successful in your patent filing (which needs to be in done in all the countries in which you wish to defend your IP). 1

Further, if granted, the patent itself does not protect your intellectual property. It just gives you the right to protect your property from non-licensed uses. This means you have to hire lawyers (again) to enforce the temporary monopoly the patent gives you. All of this is very expensive. The small inventor successfully filing for and getting adequate compensation from a patent is mostly a myth of the past-patents have become tools of large institutions (usually

\footnotetext{
${ }^{1}$ I learned all this by talking to my university's patent lawyer, an enlightening experience I recommend to all academics. See also https:/www.richardspatentlaw.com/faq/how-much-does-a-patent-cost/.
} 
private corporations) with adequate lawyers to defend against patent infringement, to be wielded as weapons in their competitive struggle for profits. It is unclear that society is actually getting benefit from this arrangement, much less whether science is thriving under it. Philosophers of science need to illuminate these kinds of deep structural issues.

Different issues arise when considering the challenge of doing work in collaboration with members of the public, particularly with communities that experience structural injustices already. Such collaborations are too be lauded (as Kevin does admirably in his book; see also Wylie 2014). But they also pose risks and pitfalls to researchers. It takes time to build up trust with segments of the public, who are often used to either neglect from academics or academics coming in, getting the data they need for publication, and leaving (or outright abuse by scientists in the worst cases) (Grasswick 2010). The time and energy commitment required not only may slow research production down (a clear challenge in this era of increased publication production pressures), but also means that the scientist will be tied to a place, a difficult thing in the hypermobile job world of academia. ${ }^{2}$ Further, while there are funding sources for such work, they are often not the high prestige ones. And, in some cases, the scientist may face agonizing decisions about how and whether to publish aspects of their research findings. This is particularly the case in situations where discoveries could be used against the populations the scientist is trying to work with. Think, for example, of health findings that could be used to increase insurance rates for some populations, or of ecological findings that if published could be used to increase resource extraction against the interests of a local population. The right kind of laws could reduce these problems (e.g., laws against discriminatory insurance rates), but scientists need help to be aware of both these potential problems and what might mitigate them. Indeed, we all need the assistance of overlapping communities to unpack the way in which values infuse the institutions and cultures in which we work. As we help scientists become more aware of the value-laden nature of their choices, we should also help them think about the complexities of doing this kind of work, of the power imbalances they are likely to encounter, and how to navigate them. Even if they don't end up pursuing such work, it would help them be more sympathetic to their colleagues who do.

Finally, consider the challenge of dangerous or "dual-use" research, where the scientist might intend some laudable end, but the performing and/or completing of which comes with potent risks. Kevin does not address such dark cases, and his book is unfailingly optimistic in its tone and in its focus on success stories. That is good, but we also need to talk about the other side of the coin. We currently lack the kinds of science governance structures we need to address potentially dangerous research. Most oversight of dangerous or dual-use research gets triggered now because a scientist wants to work with a known and listed pathogen or because they themselves recognize a concern and want help (Imperiale and Casadevall 2015). Mostly, one has to opt in to this kind of oversight. And even then, such oversight often fails badly. In the recent case of a scientist at the University of Alberta reconstructing horsepox from mail-ordered bits of DNA, he had checked with the university and the government of Canada to make sure that this was okay. Because horsepox is not an infectious agent for humans, they thought it was fine (Kupferschmidt 2017). But reconstructing any variola virus (a family to which smallpox also belongs) with mail-ordered DNA and publishing the route to success carries with it enormous security issues. (The research was privately funded.) The justification for such work was that reconstructing the virus would allow for the construction of a safer smallpox vaccine. The problem is that there is already a safer smallpox vaccine, which the researchers did not seem to be aware of (it was developed in Germany in the 1970s) (Kupferschmidt 2018). The paper was published by

\footnotetext{
${ }^{2}$ Think, for example, of the effort required to be involved with and track the kind of local debate described in Brister 2018.
}

๑ OPEN ACCESS - PTPBIO.ORG 
PLOS One, so it is available open access online. PLOS One has a dual-use oversight committee (unnamed), and that committee thought the work was acceptable to publish (Greenfieldboyce 2018; Kupferschmidt 2018). Science rejected it on the grounds that it added little scientifically and had thorny dual-use issues the journal thought not worth the risk (Kupferschmidt 2017).

This case, and others like it, raise important questions of scientists' individual value choices (Why do this research? Why publish it?) but also important questions for the governance of science. The scientist who did this research thought it was potentially important and technically interesting - the variola virus is thirty times bigger than the polio virus (which had been reconstructed in 2002), and so doing it seemed challenging and worthwhile. Consulted oversight institutions, from the initial setup to publication, seemed to agree. Many scientists, however, thought that judgment terribly mistaken (Greenfieldboyce 2018; Kupferschmidt 2018). Scientists can be dazzled by both the prospect of ready money to do work (as was the case here) and by the allure of technical sweetness (presuming "Can I do this?" is all that matters, ignoring the question of "Should I?"), and thus fail to attend properly to broader societal concerns (Douglas 2017). Governing potentially dangerous research thus requires the involvement of those not so distracted. We do not yet have structures in place to do this well, much less how to ensure the right sort of research gets examined. This problem is more about the loom of science than about the values woven into the tapestry.

We don't yet know how to govern science for general social responsibility. This is in part because the demands on scientists with respect to social responsibilities have been growing over the past half century. Fifty years ago, we were debating whether to create mandatory oversight for human subject research (Beecher 1966; Jones, Grady, and Lederer 2016). Such oversight is now commonplace, as is oversight for research using (some? most?) animals. (Whether some rodents, e.g., are excluded from such oversight depends on the jurisdiction and the funding source, another location for comparative work with normative implications.) Twenty-five years ago, aside from accepting such oversight and some ethical restrictions regarding the choice of research subjects (e.g., research to intentionally produce new bioweapons was not acceptable), the main obligation of scientists to society was to communicate their results to the public. (See, e.g., the first and second editions of the National Academy of Sciences' On Being a Scientist). Today, the standards are much higher. Consider the 2017 AAAS Statement on Scientific Freedom and Responsibility:

Scientific freedom and scientific responsibility are essential to the advancement of human knowledge for the benefit of all. Scientific freedom is the freedom to engage in scientific inquiry, pursue and apply knowledge, and communicate openly. This freedom is inextricably linked to and must be exercised in accordance with scientific responsibility. Scientific responsibility is the duty to conduct and apply science with integrity, in the interest of humanity, in a spirit of stewardship for the environment, and with respect for human rights. ${ }^{3}$

It is good a major body like the AAAS is endorsing this higher standard, particularly that science must be in the interest of humanity as a whole. (It is also evidence that the old social contract for science, which Kevin discuses on pages 169-170, is well and truly dead.) Science is too potent to not be aligned with such responsibility. But how to set the loom of science so that scientists can more readily meet this standard is much less clear. We need a philosophy of science that not just analyzes the values in science, but also understands the power relations that impinge upon, and exist within, science. We need an understanding of science in pluralist democratic societies, and how doing science in such societies should inform the shape of the loom that

\footnotetext{
${ }^{3}$ https://www.aaas.org/page/aaas-statement-scientific-freedom-responsibility
} 
makes the tapestry. In short, we need a political philosophy of science. Such clear attention to the political need not embroil philosophy of science in party politics (which is often beside the point). But we cannot pay attention to the loom of science without proper attention to the political, to issues of power, justice, and representation in a world with divergent values. With the full awareness of the importance of social and ethical values in science, it is to this broader framing that we must turn.

\section{Acknowledgments}

I wrote this essay while at the University of Waterloo, and thank that institution for the support that made possible travel to the Central APA 2018 in Chicago, where this paper was first given. I would also like to thank Ted Richards for his comments on an early draft of the paper, Elyse Purcell for suggesting an author-meets-critics session on Kevin's book, and Matt Brown (who was central to getting us organized), Kevin Elliott, and Janet Kourany for being such great collaborators in this endeavor.

\section{Literature cited}

Beecher, Henry K. 1966. “Ethics and Clinical Research.” New England Journal of Medicine 274 (24): 1354-1360.

Belt, Henk van den. 2010. "Robert Merton, Intellectual Property and Open Science: A Sociological History for our Times." In The Commodification of Academic Research: Science in the Modern University, edited by Hans Radder, 187-230. Pittsburgh: University of Pittsburgh Press.

Biddle, Justin B. 2014. "Can Patents Prohibit Research? On the Social Epistemology of Patenting and Licensing in Science." Studies in History and Philosophy of Science Part A 45: 14-23.

Brister, Evelyn. 2018. "Proceduralism and Expertise in Local Environmental Decision-Making." In $A$ Sustainable Philosophy: The Work of Bryan Norton, edited by Sahotra Sarkar and Ben Minteer. New York: Springer.

Brown, James R. 2008. “The Community of Science ${ }^{\circledR}$." In The Challenge of the Social and the Pressure of Practice: Science and Values Revisited, edited by Martin Carrier, Don Howard, and Janet Kourany, 189-216. Pittsburgh, PA: Pittsburgh University Press.

Brown, Matthew J. 2018. "Weaving Value Judgment into the Tapestry of Science.” Philosophy, Theory, and Practice in Biology 10 (10). https://doi.org/10.3998/ptpbio.16039257.0010.010.

Cavalier, Darlene, and Eric B. Kennedy, editors. 2016. The Rightful Place of Science: Citizen Science. Consortium for Science, Policy \& Outcomes.

Douglas, Heather. 2005. "Inserting the Public into Science." In Democratization of Expertise? Exploring Novel Forms of Scientific Advice in Political Decision-Making, edited by Sabine Maasen and Peter Weingart, 153-169. Dordrecht: Springer.

Douglas, Heather. 2015. "Reshaping Science: The Trouble With the Corporate Model in Canadian Government." Bulletin of the Atomic Scientists 71 (2): 88-97.

Douglas, Heather. 2016. "Values in Science." The Oxford Handbook of Philosophy of Science, edited by Paul Humphreys, 609-32. New York: Oxford University Press.

Douglas, Heather. 2017. “The Bitter Aftertaste of Technical Sweetness.” In Frankenstein: Annotated for Scientists, Engineers, and Creators of All Kinds, edited by Mary Shelley, David H. Guston, Ed Finn, Jason Scott Robert, and Charles E. Robinson. Cambridge: MIT Press.

Elliott, Kevin C. 2017. A Tapestry of Values: An Introduction to Values in Science. Oxford: Oxford University Press. 
Elliott, Kevin C. 2018a. "Précis of A Tapestry of Values: An Introduction to Values in Science." Philosophy, Theory, and Practice in Biology 10 (7). https://doi.org/10.3998/ptpbio.16039257.0010.007.

Elliott, Kevin C. 2018b. "A Tapestry of Values: Response to My Critics." Philosophy, Theory, and Practice in Biology 10 (11). https://doi.org/10.3998/ptpbio.16039257.0010.011.

Elliott, Kevin C., and Daniel J. McKaughan. 2014. "Nonepistemic Values and the Multiple Goals of Science.” Philosophy of Science 81 (1): 1-21.

Grasswick, Heidi E. 2010. "Scientific and Lay Communities: Earning Epistemic Trust Through Knowledge Sharing.” Synthese 177 (3): 387-409.

Greenfieldboyce, Nell. 2018. "Did Pox Virus Research Put Potential Profits Ahead of Public Safety?" National Public Radio, February 17, 2018. https:/www.npr.org/sections/health-shots/2018/02/ 17/585385308/did-pox-virus-research-put-potential-profits-ahead-of-public-safety.

Imperiale, Michael J., and Arturo Casadevall. 2015. "A New Synthesis for Dual Use Research of Concern." PLoS Medicine 12 (4): e1001813.

Jones, David S., Christine Grady, and Susan E. Lederer. 2016. "Ethics and Clinical Research'-The 50th Anniversary of Beecher's Bombshell." New England Journal of Medicine 374 (24): 23932398.

Kevles, Daniel. 2002. A History of Patenting Life in the United States with Comparative Attention to Europe and Canada: A Report to the European Group on Ethics in Science and New Technologies. Office for Official Publications of the European Communities.

Kondro, Wayne. 2002. “Canadian High Court Rejects OncoMouse.” Science 298 (5601): 2112-2113.

Kourany, Janet A. 2018. "Adding to the Tapestry." Philosophy, Theory, and Practice in Biology 10 (9). https://doi.org/10.3998/ptpbio.16039257.0010.009.

Kupferschmidt, Kai. 2017. “Labmade Smallpox Is Possible, Study Shows.” Science 357 (6347): 115116.

Kupferschmidt, Kai. 2018. “Critics See Only Risks, No Benefits in Horsepox Paper.” Science 359 (6374): 375-376.

Naylor, C. D., R. J. Birgeneau, M. Crago, M. Lazaridis, C. Malacrida, A. B. McDonald, and A. Wilson. 2017. "Canada's Fundamental Science Review. Investing in Canada's Future: Strengthening the Foundations of Canadian Research.” http://www.sciencereview.ca/eic/site/059.nsf/eng/home

Parthasarathy, Shobita. 2017. Patent Politics: Life Forms, Markets, and the Public Interest in the United States and Europe. Chicago: University of Chicago Press.

Reiss, Julian. 2010. "In Favour of a Millian Proposal to Reform Biomedical Research.” Synthese 177 (3): 427-447.

Wylie, Alison. 2014. "Community-Based Collaborative Archaeology." In Philosophy of Social Science: A New Introduction, edited by Nancy Cartwright and Eleonora Montuschi, 68-82. Oxford: Oxford University Press.

(C) 2018 Author(s)

This is an open-access article distributed under the terms of the Creative Commons AttributionNonCommercial-NoDerivatives 4.0 International license, which permits anyone to download, copy, distribute, or display the full text without asking for permission, provided that the creator(s) are given full credit, no derivative works are created, and the work is not used for commercial purposes. 